\title{
Spatiotemporal evolution of land surface temperature of Lake Oubeira catchment, northeastern Algeria
}

\author{
Chouaib REZZAG BARA ${ }^{1) \text { ABCDEF }}$, Mohamed DJIDEL ${ }^{2) A B D E} \bowtie$, \\ Fethi MEDJANI ${ }^{3)}$ CDEF , Sofiane LABAR $^{4) ~ B C D E}$
}

\footnotetext{
1) University Kasdi Merbah Ouargla, Geology of the Sahara Laboratory, Ouargla, Algeria; e-mail: choaib1907@gmail.com

${ }^{2)}$ orcid.org/0000-0002-6212-9817; University Kasdi Merbah Ouargla, Geology of the Sahara Laboratory, BP 511, 30000 Ouargla, Algeria; email: djidelm@yahoo.fr

3) orcid.org/0000-0002-1454-5007; University Kasdi Merbah Ouargla, Geology of the Sahara Laboratory, Ouargla, Algeria; e-mail: medjanifethi@yahoo.fr

4) orcid.org/0000-0002-5943-4546; University Chadli Bendjedid El-Tarf, Faculty of Natural and Life Sciences, El-Tarf, REDD Laboratory, Annaba, Algeria; e-mail: labar_sf@yahoo.fr
}

For citation: Rezzag Bara C., Djidel M., Medjani F., Labar S. 2019. Spatiotemporal evolution of land surface temperature of Lake Oubeira catchment, northeastern Algeria. Journal of Water and Land Development. No. 43 (X-XII) p. 151-157. DOI: 10.2478/jwld-2019-0073.

\begin{abstract}
The difficulties of access and detailed measurements of land surface temperature (LST) and water surface temperature (WST) especially in wetlands made the use of remote sensing data as one of the sources and techniques to estimate many climate elements including surface temperature and surface emissivity $(\varepsilon)$. This study aims to estimate the surface temperature of the wetland of Lake Oubeira located in northeastern Algeria and their spatiotemporal evolution in both land and water. Landsat OLI-TIRS images in two dates (April and September 2016) obtained from the USGS have been used in this work, and forms the basis of a series of operations to obtain the final LST: development of the normalized difference vegetation index $(N D V I)$, conversion of the digital number $(D N)$ of the thermal infrared band (TIR) into spectral radiance as well as the calculation of the effective luminosity temperature of the sensor from the spectral radiation and surface emissivity $(\varepsilon)$.

The results show that the $L S T$ varies in space and time (from 16 to $31^{\circ} \mathrm{C}$ in April and from 24 to $41^{\circ} \mathrm{C}$ in September). This implies that the absorption of the equilibrium temperature at land cover depends on the optical properties of the surface, which are essentially determined by its water content, colour and morphology. At the same time, the water surface is the lowest land cover temperature, which also has a spatial variation (from 19 to $25^{\circ} \mathrm{C}$ in April and from 26 to $34.5^{\circ} \mathrm{C}$ in September) induced by atmospheric temperature, wind direction and speed and the depth of the lake.
\end{abstract}

Key words: emissivity, lake basin, land surface temperature (LST), normalized different vegetation index (NDVI), SEBAL, water surface temperature (WST)

\section{INTRODUCTION}

Wetland assessments have identified a total number of 1,497 wetland sites in 2006, which are distributed in 52 habitat types [SAIFOUNI 2009]. Dams, sebkhas and lakes represent the most important habitat in Algeria. The majority of Algerian wetlands are continental, and are abundant in the North-East of the country. The Algerian sites included in the list of the Ramsar Convention on Wetlands of
International Importance [CAESSTEKER 2007], are 26 of the 250 wetlands listed between 1982 and 2002, one of them Lake Oubeira (registered in November 1983). Lake Oubeira, the subject of this study, is located in northeastern Algeria. This lake was completely drained at the end of the summer of 1990 as a result of major pumping operations to supply drinking water and a dry year season [MOUISSI, ALAYAT 2016]. 
Land surface temperature (LST) is a climate element that plays an important role in the monitoring of spatiotemporal water evolution and its effects on the ecosystem throughout the region, so that a number of mathematical equations and algorithms have been found and designed to estimate the values of the earth's surface temperature. The methods used to estimate this parameter are based on data obtained from meteorological stations or other data sources where the area has no such station, remote sensing data is one of the sources and techniques used to estimate many climate elements including LST. The thermal mapping can provide a discrimination between the temperatures of seawater and water polluted by uncontrolled human activity [FAOUR et al. 2004]. The modelling of the energy balance equation by SEBAL (surface energy balance algorithm for land) is based on the surface parameters derived from the satellite sensor, namely the emissivity surface, vegetation index and surface temperature [BASTIAANSSEN et al. 1998; BASTIAANSSEN 2000; MEHOR et al. 2009; MOLNÁR 2016].

The main objective of the present study is to estimate the temperature of the land surface of the Lake Oubeira basin and their spatiotemporal evolution at both soil and water using SEBAL algorithm and the Landsat 8 OLI-TIRS satellite image. Remote sensing by thermal infrared bands $(T I R)$ permits the collection, analysis and modelling of environmental parameters. It is used to calculate the land surface temperature (LST), which is an important factor in many environmental processes, including global warming or heat islands.

\section{MATERIAL AND METHODS}

\section{STUDY AREA}

The Oubeira watershed is located $5 \mathrm{~km}$ South-West of El Kala and $54 \mathrm{~km}$ East of Annaba. It is located in the wilaya of El-Tarf in the extreme North-East of Algeria, at the Tunisian frontier (Fig. 1). Lake Oubeira has an average area of 2,100 ha and a perimeter of about $20 \mathrm{~km}$, and is



Fig. 1. The Oubeira watershed location; source: own elaboration located in a watershed of 8,500 ha. The Oubeira is an almost circular basin with no flow towards the sea (it is an endorheic system); land in the watershed is shared between the forest estate where private plots are scarce, and largely privately owned agricultural land used mainly for groundnuts, market gardening and grazing [MESSERER 1999].

The Oubeira is a permanent freshwater lake. It is a basin with a more or less flat bottom slightly inclined towards the North, of natural origin having a maximum depth of $4 \mathrm{~m}$, the average depth being $1.24 \mathrm{~m}$. This first depth is the roof of a layer of mud whose average depth is $1.30 \mathrm{~m}$ and a maximum value of $2.50 \mathrm{~m}$. The bottom of the latter constitutes the real substratum of the lake with a concave shape inclined towards the South-West. The lake contains a volume of silt of $30.2 \mathrm{mln} \mathrm{m}^{3}$, but its volume of water varies according to the season [ALAYAT et al. 2009]. In summer, the lake contains a volume of water around 22 $\mathrm{mln} \mathrm{m}^{3}$ with an average depth of $0.96 \mathrm{~m}$ and in winter water can reach $32 \mathrm{mln} \mathrm{m}^{3}$ with an average depth of $1.24 \mathrm{~m}$.

The geology of the region is very complex because of numerous overlapping surfaces and faults which have had numerous replayings and disturb the successions of essentially sedimentary formations, especially during the alpine phases [DURAND DELGa 1969; JOLEAUd 1936; RAOULT 1974; VILA 1980]. The substrate is entirely composed of Tertiary-sized Numidian clay, with the presence of Quaternary deposits all around the lake. The silty alluvium of the Quaternary valley floor is located southeast of the lake.

Lake Oubeira drains the watershed in its centre through four wadis, the main one being the Wadi Messida to the South-East, which collects floodwater from the Wadi El-Kebir North of El-Tarf. In summer, the hydrological system operates in the opposite direction, giving this wadi the characteristic of flowing in both directions (tributary and emissary). Other tributaries of the lake are the Wadi Demnet Errihane in the North, the Wadi Boumerchene in the NorthEast, the Wadi Degrah in the East and the small tributaries of the surrounding hills, which form riparian forests. Oubeira is an endorheic lake that serves as a reservoir to control the sometimes spectacular floods of the El-Kebir River. In addition, it receives sediments from the watershed transported by floodwaters [BOUCHEHED et al. 2017].

Groundwater supplies water bodies through resurgences in streams and an underground flow.

The region of El-Kala, is placed in a subhumid climate with warm winter and permanent winds dominating North-West. The average annual rainfall is between 700 and 800 $\mathrm{mm}$ and is mainly from early October until the end of March. The region is characterized by two seasons, one dry from May to September and the other wet from September to April. The temperature of the water varies from 8.8 to $15.2^{\circ} \mathrm{C}$ in the month of January. The average air temperature, calculated over a period of 30 years from 1987 to 2016 is $17.50^{\circ} \mathrm{C}$ with $11.65^{\circ} \mathrm{C}$ for January the coldest month and with an average of $25^{\circ} \mathrm{C}$ in August which is the hottest month. The average evaporation is $74.15 \mathrm{~mm}$, with a maximum of $152.08 \mathrm{~mm}$ and a minimum of $22.47 \mathrm{~mm}$. The waters of the lake are very turbid, especially in winter (1.0-1.5 $\mathrm{m}$ Secchi disc in 1976) with a $\mathrm{pH}$ ranging between 8 and 10.65 . 
Landsat 8 uses two distinct imaging payloads. The Operational Land Imager (OLI) covers the visible and near-infrared (VNIR) and shortwave infrared (SWIR) portions of the spectrum, while the Thermal Infrared Sensor (TIRS) adds two long-wave thermal spectral channels, one centered at $10.9 \mu \mathrm{m}$ (band 10) and a second centered at $12.0 \mu \mathrm{m}$ (band 11). Data from both instruments is combined to create integrated Landsat 8 image data products (Tab. 1). The guarantee of the geometric registration of OLI and TIRS data is essential to the quality of the Landsat 8 product. Thermal infrared remote sensing consists in measuring the radiative energy emitted by the earth's surface, which makes it possible to deduce the surface temperature. Therefore, by detecting the emitted radiation, it is possible to map small changes in temperature at the sea surface and identify thermal anomalies [JENSEN 2000]. Most of the work done in recent years has resulted in maps of the surface temperature of a spatially resolved body of water with the OLI-TIRS sensor data. The 2 bands 10 and 11 of the LANDSAT- 8 satellite TIRS sensor are designed to detect the land surface temperature.

Table 1. Characteristics of Landsat 8 Operational Land Imager-Thermal Infrared Sensor (OLI-TIRS)

\begin{tabular}{|l|l|c|c|c|}
\hline Bands type & Band & Name & Wavelength $(\mu \mathrm{m})$ & Resolution $(\mathrm{m})$ \\
\hline \multirow{4}{*}{ Visible } & Band 2 & Blue & $0.45-0.51$ & 30 \\
\cline { 2 - 5 } & Band 3 & Green & $0.53-0.59$ & 30 \\
\cline { 2 - 5 } & Band 4 & Red & $0.63-0.67$ & 30 \\
\hline \multirow{2}{*}{$\begin{array}{l}\text { Near and } \\
\text { shortwave } \\
\text { infrared }\end{array}$} & Band 5 & NIR & $0.85-0.88$ & 30 \\
\cline { 2 - 5 } & Band 6 & SWIR 1 & $1.57-1.65$ & 30 \\
\cline { 2 - 5 } $\begin{array}{l}\text { Thermal } \\
\text { infrared }\end{array}$ & Band 7 & SWIR 2 & $2.11-2.29$ & 30 \\
\cline { 2 - 5 } & Band 10 & TIRS 1 & $10.6-11.19$ & 100 \\
\hline
\end{tabular}

Source: USGS EROS Archive [undated].

\section{WATERSHED DELINEATION}

Study area landscape, which includes drainage subbasins and topography, was a very important consideration in creating thematic maps. Topographical map using Shuttle Radar Topography Mission Digital Elevation Model (SRTM 1 Arc_Second) at $30 \mathrm{~m}$ spatial resolution was used as main data source. After importing the DEM file scene "n36e008" into ArcMap, the first step is projected DEM into a coordinate system in which the horizontal units of the $x y$ coordinates are in meters, not degrees. DEMs are based on watershed realization using the "Spatial Analyst tools" computational watershed application, wherein the highest sensitivity zones could be extrapolated [METZ et al. 2011]. It is important to remove all depressions or sinks in the elevation grid from the DEM layer using the "Fill" function of the "Hydrology toolbox", Sinks in elevation data are most commonly due to errors in the data. These errors are often caused by sampling effects and the rounding of elevations to integer numbers [METZ et al. 2011]. The "flow direction" raster is generated from the DEM, shows the actual direction of water flow. To create a stream network, use the "flow accumulation" tool to calculate the number of upslope cells flowing to a location [BOUguerRA et al. 2017]. "Flow Accumulation" defines a Stream Network by use the "Stream to Feature" tool in
ArcGIS to convert the grid to a linear vector file (shapefile). Extract Stream orders, run "Snap Pour Point" to snap the pour points to the nearest point of highest flow accumulation (outlet used in a watershedding operation). Delineate watersheds using the "Watershed" function of the "Hydrology" toolbox. Convert the Watershed layer from a raster to polygon (vector) format before assigning their attributes in the next section of the methodology like a mask (Fig. 2).

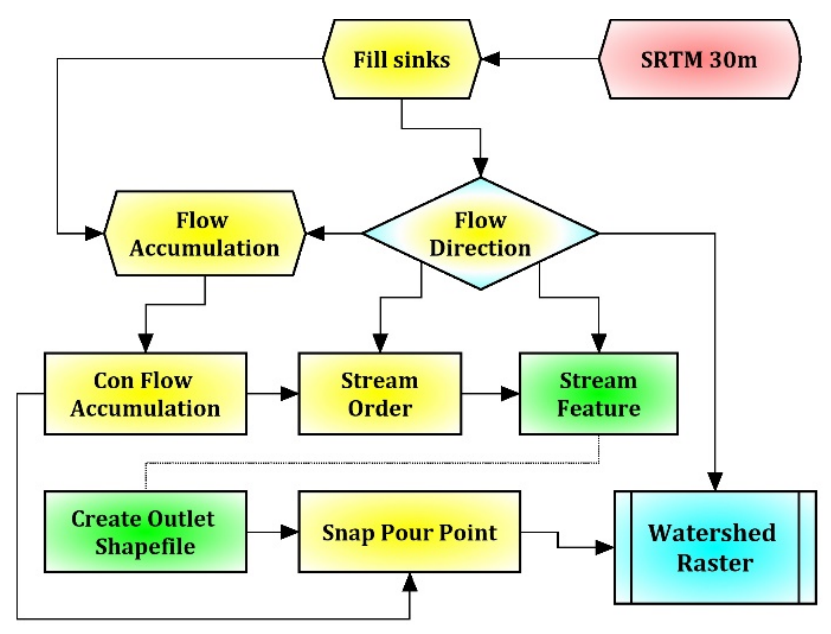

Fig. 2. Flow chart for watershed delineation; source: own elaboration

\section{LAND SURFACE TEMPERATURE (LST)}

We used Operational Land Imager (OLI) and Thermal Infrared Sensor (TIRS) of Landsat 8 image covering the study area with Path 193/Row 35 that had no cloud cover, observed from 12.04.2016 and 03.09.2016.

We used the approach for processing Landsat images as provided in SINGH et al. [2014]. The digital number $(D N)$ values were first converted to radiance and then to reflectance. The land surface temperature $(L S T)$ values were derived from Landsat 8 thermal data, specifically TIRS bands 10 and 11. For this purpose, the SEBAL approach incorporated a set of algorithms composed of commonly used calibration steps and atmospheric correction techniques (Fig. 3).

- Conversion OLI to TOA reflectance:

OLI band data can also be converted to Top Of Atmosphere (TOA) planetary reflectance using reflectancerescaling coefficients provided in the product metadata file (MTL file). The following equation is used to convert $D N$ values to TOA reflectance for OLI data as follows [BARSI et al. 2014]:

$$
\rho_{\lambda}{ }^{\prime}=M_{\rho} \cdot Q_{c a l}+A_{\rho}
$$

Where: $\rho_{\lambda}{ }^{\prime}=$ TOA planetary reflectance, without correction for solar angle - note that $\rho \lambda^{\prime}$ does not contain a correction for the sun angle; $M_{\rho}=$ band-specific multiplicative rescaling factor from the metadata (Reflectance Multi Band $x$, where $x$ is the band number); $A_{\rho}=$ band-specific additive rescaling factor from the metadata (Reflectance Add Band $x$, where $x$ is the band number); $Q_{c a l}=$ quantized and calibrated standard product pixel values $(D N)$. 




Fig. 3. Flow chart for calculate land surface temperature; source: own elaboration

TOA reflectance with a correction for the sun angle is then:

$$
\rho_{\lambda}=\frac{\rho_{\lambda}^{\prime}}{\cos \left(\theta_{S Z}\right)}=\frac{\rho_{\lambda}^{\prime}}{\sin \left(\theta_{S E}\right)}
$$

Where: $\rho_{\lambda}=$ TOA planetary reflectance; $\theta_{S E}=$ local sun elevation angle - the scene center sun elevation angle in degrees is provided in the metadata (sun elevation); $\theta_{S Z}=$ local solar zenith angle $-\theta_{S Z}=90^{\circ}-\theta_{S E}$.

For more accurate reflectance calculations, per pixel solar angles could be used instead of the scene center solar angle, but per pixel solar zenith angles are not currently provided with the Landsat 8 products.

- Surface emissivity $(\varepsilon)$

The surface emissivity is a factor that describes the efficiency of an object radiates energy in comparing with brightness temperature [REUTTER et al. 1994]. TIRS band data can be converted from spectral radiance to brightness temperature using the thermal constants provided in the MTL file [UGUR, GORDANA 2016]:

$$
T_{b}=\frac{\mathrm{K}_{2}}{\ln \left(\frac{\mathrm{K}_{1}}{L_{\lambda}}+1\right)}
$$

Where: $T_{b}=$ black body temperature at satellite $(\mathrm{K}) ; \mathrm{K}_{1}$ and $\mathrm{K}_{2}=$ calibration constants for Landsat- 8 thermal bands (Tab. 2), $L_{\lambda}=$ spectral radiance $\left(\mathrm{W} \cdot\left(\mathrm{m}^{2} \cdot \mathrm{sr} \cdot \mu \mathrm{m}\right)^{-1}\right)$, and is calculated by the following equation [WENG, SCHUBRING 2004]:

$$
L_{\lambda}=0.0370588 D N+3.2
$$

To compute the land surface temperature, the black body temperature is corrected with respect to the surface emissivity $(\varepsilon)$ values. The surface emissivity is a factor that describes the efficiency of an object radiates energy in comparing with black body. The values of emissivity are estimated from $N D V I$ and $L A I$ as follows:
Table 2. Constants for Landsat 8 Thermal Infrared Sensor (TIRS) bands

\begin{tabular}{|c|c|r|r|}
\hline $\begin{array}{c}\text { Types of } \\
\text { constant factors }\end{array}$ & $\begin{array}{c}\text { Constants } \\
\text { for TIRS bands }\end{array}$ & Band 10 & Band 11 \\
\hline \multirow{2}{*}{ Rescaling factor } & $\mathrm{M}_{\rho}$ & 0.000342 & 0.000342 \\
\cline { 2 - 4 } & $\mathrm{A}_{\rho}$ & 0.10000 & 0.10000 \\
\hline \multirow{2}{*}{ Thermal constant } & $\mathrm{K}_{1}$ & 774.8853 & 480.8883 \\
\cline { 2 - 4 } & $\mathrm{K}_{2}$ & 1321.0789 & 1201.1442 \\
\hline
\end{tabular}

Source: own elaboration.

$$
\varepsilon=1009+0.047 \ln (N D V I)
$$

Where $N D V I>0$, otherwise is assumed to be zero (e.g. water).

$$
\varepsilon=0.97+0.0033 L A I
$$

For $L A I<3.0, \varepsilon=0.98$ when $L A I>3$.

For water, $N D V I<0$ and surface albedo $<0.47, \varepsilon=0.985$. For snow, $N D V I<0$ and surface albedo $\geq 0.47, \varepsilon=0.985$.

- Normalized difference vegetation index (NDVI)

The NDVI is the ratio of the differences in reflectivities for the near-infrared band (B5) and the red band (B4) to their sum [LAOSUWAN, UTTARUK 2017; SIERRA-SOLER et al. 2015]:

$$
N D V I=\frac{\rho_{\mathrm{NIR}}-\rho_{\mathrm{Red}}}{\rho_{\mathrm{NIR}}+\rho_{\mathrm{Red}}}
$$

Where B5 and B4 are reflectivities for bands 5 and 4 and are found in the output file. The NDVI is a sensitive indicator of the amount and condition of green vegetation. Values for $N D V I$ range between -1 and +1 . Green surfaces have a $N D V I$ between 0 and 1 and water and cloud are usually less than zero.

Soil adjusted vegetation index $(S A V I)$ need to be calculated first.

The $S A V I$ is an index that attempts to "subtract" the effects of background soil from NDVI so that impacts of soil wetness are reduced in the index. It is computed as [HUETE 1988]:

$$
S A V I=\frac{(1+L)\left(\rho_{\mathrm{NIR}}-\rho_{\mathrm{Red}}\right)}{\left(L+\rho_{\mathrm{NIR}}+\rho_{\mathrm{Red}}\right)}
$$

Where $L$ is a constant, which depends on the area properties, $L \approx 0.5$ is used.

\section{- Leaf Area Index (LAI)}

The $L A I$ is the ratio of the total area of all leaves on a plant to the ground area represented by the plant. It is an indicator of biomass and canopy resistance. LAI is computed for southern Idaho using the following empirical equation [ALLEN et al. 2002; 2007]:

$$
L A I=\frac{-\ln (0.69-S A V I / 0.59)}{0.91}
$$

- Corrected thermal radiance $\left(R_{c}\right)$

The corrected thermal radiance from the surface $\left(R_{c}\right)$ is calculated following [WUKELIC et al. 1989] as:

$$
R_{c}=\frac{L_{N B}-R_{p}}{\tau_{N B}}-(1-\varepsilon) R_{\text {sky }}
$$

Where: $L_{\mathrm{NB}}=$ the spectral radiance of bands 10 and 11 $\left(\mathrm{W} \cdot\left(\mathrm{m}^{2} \cdot \mathrm{sr} \cdot \mu \mathrm{m}\right)^{-1}\right) ; R_{p}=$ the path radiance in the 10.4-12.5 $\mu \mathrm{m}$ band $\left(\mathrm{W} \cdot\left(\mathrm{m}^{2} \cdot \mathrm{sr} \cdot \mu \mathrm{m}\right)^{-1}\right) ; R_{\text {sky }}=$ the narrow band down- 
ward thermal radiation for a clear sky $\left(\mathrm{W} \cdot\left(\mathrm{m}^{2} \cdot \mathrm{sr} \cdot \mu \mathrm{m}\right)^{-1}\right)$; $\tau_{\mathrm{NB}}=$ the narrow band transmissivity of air (10.6-12.5 $\mu \mathrm{m})$. Unit for $R_{c}$ is $\mathrm{W} \cdot\left(\mathrm{m}^{2} \cdot \mathrm{sr} \cdot \mu \mathrm{m}\right)^{-1}$.

The corrected thermal radiance $\left(R_{c}\right)$ using mean values for path radiance, narrow band downward thermal radiation, and narrow band transmissivity of air [WUKELIC et al. 1989].

In the absence of values for these terms, they can be ignored by setting $R_{\mathrm{p}}=0$ and $\tau_{\mathrm{NB}}=1$ and the $R_{\text {sky }}$ term can also be ignored by setting $R_{\text {sky }}=0$. This converts $R_{c}$ into an uncorrected radiance $\left(L_{\mathrm{NB}}\right)$. Fortunately, the effects of the three parameters on $R_{c}$ are largely self-canceling. However, the result of no correction to $L_{\mathrm{NB}}$ will be a general underestimation of surface temperature $(L S T)$ by up to about $5^{\circ} \mathrm{C}$ for warmer portions of an image.

- Land surface temperature (LST)

$L S T$ is computed using the following modified Plank equation [ALLEN et al. 2007]:

$$
L S T=\frac{\mathrm{K}_{2}}{\ln \left(\frac{\varepsilon_{N B} \mathrm{~K}_{1}}{R_{C}}+1\right)}
$$

Where: $R_{c}$ is the corrected thermal radiance from the surface; $K_{1}$ and $K_{2}$ are constants for Landsat images (Tab. 2). Units for $R_{c}$ must be the same as those for $\mathrm{K}_{1}$.

\section{RESULTS AND DISCUSSION}

\section{SPATIAL DISTRIBUTION OF LAND USE SURFACE TEMPERATURE (LST)}

The results of the estimations for the SEBAL model were evaluated with maps of the spatial distribution of surface temperature ( $L S T)$. The derived $L S T$ values show surface temperature between 16 and $31^{\circ} \mathrm{C}$ in April (12.04.2016) and between 24 and $41^{\circ} \mathrm{C}$ in September (03.09.2016).

The estimated LST map (Fig. 4a) revealed a spatial variation between surface temperature values as a function of the existing land cover in the spring. This map shows that water surfaces have the lowest temperatures (16$21^{\circ} \mathrm{C}$ ) while bare soils have high temperatures $\left(25-31^{\circ} \mathrm{C}\right)$ as well as vegetation, and urban surfaces have intermediate temperatures $\left(20-26^{\circ} \mathrm{C}\right)$.

As a result, it indicates which surfaces have a high absorption factor in the visible. Dark surfaces reach higher equilibrium temperatures than surfaces with a lower absorption factor (which are therefore clearer).

Figure $4 \mathrm{~b}$ presents a spatial temperature $(L S T)$ variation map in the fall season with temperatures ranging from 24 to $41^{\circ} \mathrm{C}$ depending on the type of existing land cover. This map shows that water surfaces always have the lowest temperatures $\left(24-30^{\circ} \mathrm{C}\right)$ and bare soils have high temperatures $\left(35-41^{\circ} \mathrm{C}\right)$ as well as vegetation and urban surfaces have the temperatures intermediates (from 30 to $36^{\circ} \mathrm{C}$ ).

This indicates that the land cover areas have almost the same solar-ray absorption behaviour with respect to the change of season (same spatial distribution) with an increase of the temperature of each surface from 8 to $9^{\circ} \mathrm{C}$ between April and September. The interval of each map shows an increase of $2^{\circ} \mathrm{C}, 15^{\circ} \mathrm{C}$ to April and $17^{\circ} \mathrm{C}$ to September.
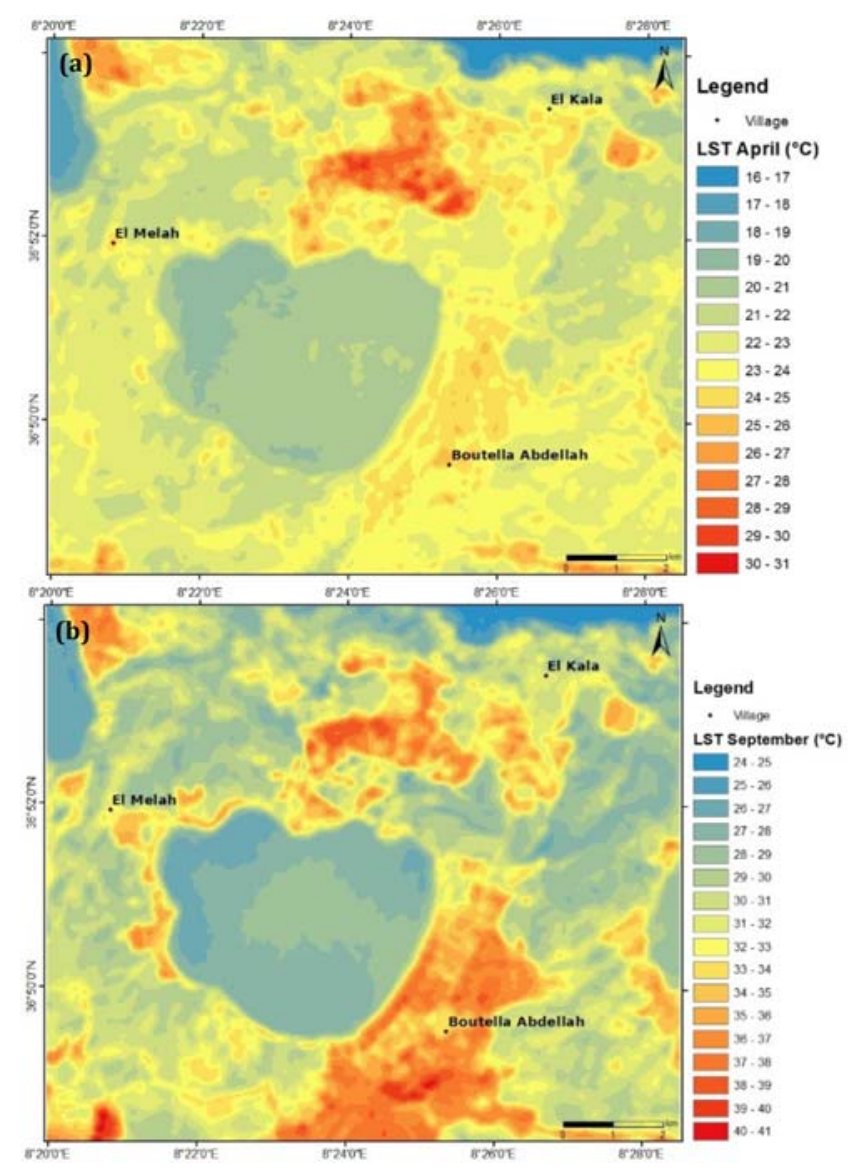

Fig. 4. Spatial distribution of land surface temperature (LST) in: (a) April 2016, (b) September 2016; source: own study

\section{SPATIAL DISTRIBUTION OF WATER SURFACE TEMPERATURE (WST)}

The surface temperature of Lake Oubeira shows a spatial variation of 19 to $25^{\circ} \mathrm{C}$ in April (high water period) indicating an interval of $6^{\circ} \mathrm{C}$ (Fig. 5a). This distribution of temperature decreases from the periphery with temperatures from 22 to $25^{\circ} \mathrm{C}$ by very shallow and wet soils, to the center of the lake. The latter also shows a spatial variability that is relatively high from East to center (from 20.0 to $21.5^{\circ} \mathrm{C}$ ) and surrounded by temperatures $<20^{\circ} \mathrm{C}$.

In September the spatial variation of the LST is 26 to $34.5^{\circ} \mathrm{C}$ with an interval of $8.5^{\circ} \mathrm{C}$ (low water period) - Figure $5 \mathrm{~b}$. In the periphery it is from 20 to $34.5^{\circ} \mathrm{C}$ and going towards the center there is always some variability that comes with a relatively high temperature (from 27.5 to $29^{\circ} \mathrm{C}$ ) from the east to the center of the lake. It is surrounded by the lowest temperatures of 26 to $27.5^{\circ} \mathrm{C}$.

This indicates that the surface water temperature of Lake Oubeira has an almost similar spatial behaviour in both seasons, with an increase in the temperature of each surface of approximately $8^{\circ} \mathrm{C}$ between April and September, as well as the interval each map is $15^{\circ} \mathrm{C}$ to April and $17^{\circ} \mathrm{C}$ to September.

This spatial distribution of lake surface temperature is the result of landforms and forests around the lake as well as climatic conditions by temperature and wind speed and direction. Wind-induced lake currents play a key role in 


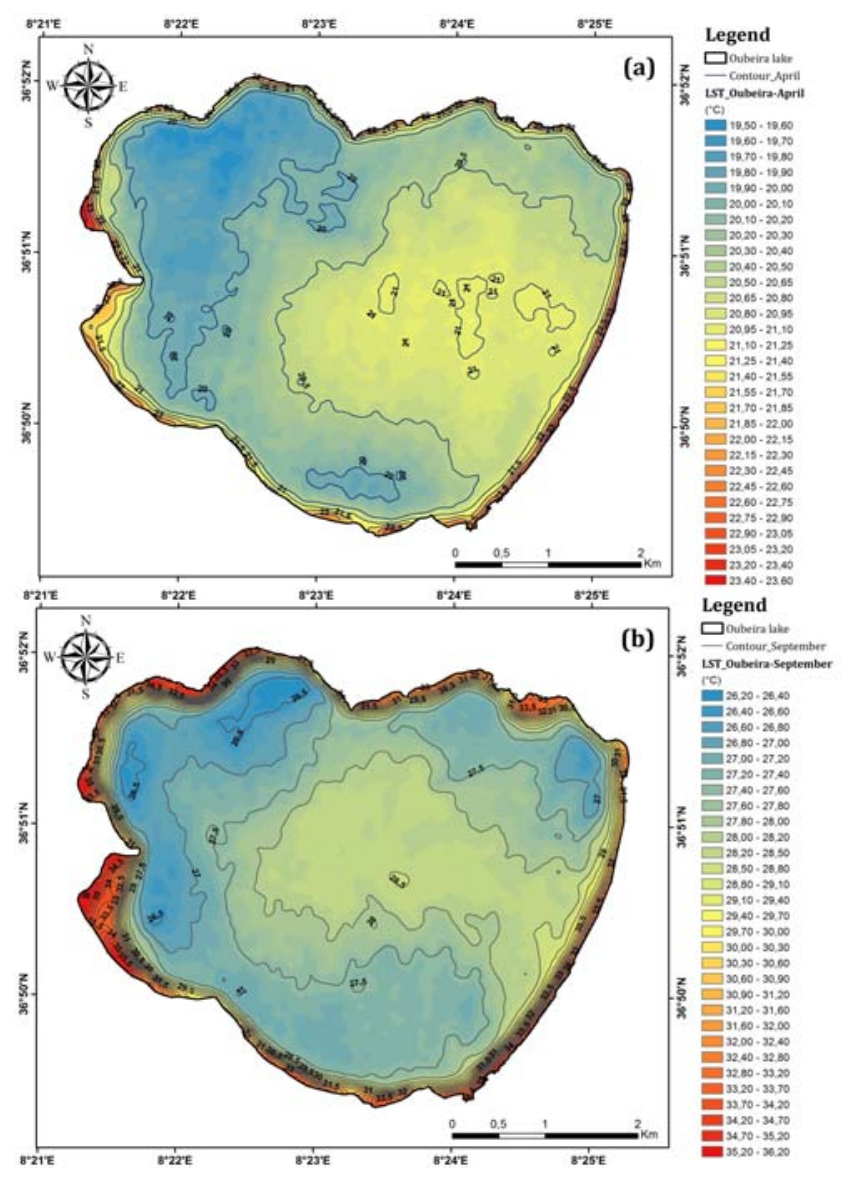

Fig. 5. Spatial distribution of water surface temperature (WST) in Lake Oubeira in: (a) April 2016, (b) September 2016; source: own study

the dynamics of aquatic ecosystems that affect the transport of dissolved substances, the mixing of the lake water column and the resuspension of bottom sediments [PODSETCHINE, SCHERNEWSKI 1999].

\section{CONCLUSIONS}

It is difficult, in particular in wetlands, to measure the temperature of the earth's surface in a detailed way. Environmental satellite data is an efficient and inexpensive way to estimate the surface temperature of a region. This research aims to show the contribution of remote sensing in studying the temperature of the land surface of Lake Oubeira.

The results show that the temperature of the earth's surface varies over space and time. This is one of the important parameters for studying the distribution of temperature in both soil and water. In vegetation cover, the absorption of the equilibrium temperature depends on the optical properties of the surface, dependent on its water content, colour and morphology.

The study showed that the recovery of land surface temperature $(L S T)$ from surface emissivity and normalized difference vegetation index $(N D V I)$ has a spatiotemporal variation over time depending on land use and even the lake water surface of $2,100 \mathrm{ha}$, as a consequence of the currents induced by the wind as well as the reliefs and forests around the lake.

\section{REFERENCES}

Alayat H., Kherici N., Lamouroux C. 2009. Evolution Spatiale De L'envasement Du Lac Oubeira Impose Par L'erosion (extreme Ne Algerien) [Space evolution of the silting of Oubeira Lake imposed by erosion (extreme Ne Algerian)]. Le Journal de l'Eau et de l'Environnement. Vol. 8. No. 15 p. 28-42.

Allen R.G., TAsumi M., TrezZA R. 2007. Satellite-based energy balance for mapping evapotranspiration with internalized calibration (METRIC)-Model. Journal of Irrigation and Drainage Engineering. Vol. 133 p. 380-394.

Allen R.G., TREZZA R., TASUMI M. 2002. SEBAL Surface energy balance algorithms for land. Idaho Implementation. Advance training and user's manual, version 1.0. Kimberly. The Idaho Department of Water Resources pp. 98.

BARSi J.A., SchOtT J.R., HoOK S.J., RaQUENO N.G., Markham B.L., RADOCINSKI R.G. 2014. Landsat-8 thermal infrared sensor (TIRS) vicarious radiometric calibration. Remote Sensing. Vol. 6 (11) p. 11607-11626. DOI 10.3390/rs61111607.

BASTIAANSEEN W.G.M. 2000. SEBAL-based sensible and latent heat fluxes in the irrigated Gediz Basin, Turkey. Journal of Hydrology. Vol. 229. Iss. 1-2 p. 87-100. DOI 10.1016/ S0022-1694(99)00202-4.

Bastiaanssen W.G.M., Menenti M., Feddes R.A., Holslag A.A.M. 1998. Remote sensing surface energy balance algorithm for land (SEBAL) - Formulation. Journal of Hydrology. Vol. 212-213 p. 198-212.

Bouchehed H., Mihoubi M.K., Derdous O., Djemili L. 2017. Evaluation of potential dam break flood risks of the cascade dams Mexa and Bougous (El Taref, Algeria). Journal of Water and Land Development. No. 33 p. 39-45. DOI 10.1515/ jwld-2017-0017.

Bouguerra H., Bouanani A., Khanchoul K., Derdous O., TACHI S.E. 2017. Mapping erosion prone areas in the Bouhamdane watershed (Algeria) using the Revised Universal Soil Loss Equation through GIS. Journal of Water and Land Development. No. 32 p. 13-23. DOI 10.1515/jwld-20170002.

CAessteker P. 2007. Statut des inventaires des zones humides dans la Région Méditerranéenne. Ver. 2.0. [Status of wetland inventories in the Mediterranean Region]. Centre de recherche pour la conservation des zones humides méditerranéennes, Fondation Tour du Valat, France pp. 268.

DuRAND Delga M. 1969. Mise au point sur la structure du NordEst de la Berberie [Update on the structure of the North-East of Berberia]. Service de publication, Carte géologique de l'Algérie Bulletin de la Société géologique de France, Paris (7), XIII pp. 131.

Faour G., Shaban A., Jaquet J. 2004. Apport de la bande infrarouge thermique du capteur Etm + De Landsat-7 dans la détection de la pollution de l'eau de mer sur le littoral libanais [Contribution of the thermal infrared band of the Landsat-7 $\mathrm{Etm}+$ sensor in the detection of seawater pollution on the Lebanese coast]. Télédétection. Vol. 4(2) p. 197-209.

HuETE A.R. 1988. A soil-adjusted vegetation index (SAVI). Remote Sensing of Environment. Vol. 25. Iss. 3 p. 295-309.

JENSEN J.R. 2000. Remote sensing of the environment: An earth resources perspective. New Jersey, USA. Prentice-Hall, Upper Saddle River. ISBN 0-13-489733-1 pp. 544.

JOLEAUD L. 1936. Etude géologique de la région de Bône-la Calle [Geological study of the Bône-la Calle region]. Bulletin du Service de la Carte Géologique de L’Algérie. 2é série. Stratigraphie - descriptions regionales. No. 12 pp. 199.

LAOSUWAN T., UTTARUK Y. 2017. Carbon sequestration assessment of the orchards using satellite data. Journal of Ecological Engineering. Vol. 18(1) p. 11-17. DOI 10.12911/ 22998993/66257. 
Mehor M., Hamimed A., Khaldi A., Seddini A., Abdesselam B. 2009. Spatialisation de la température et des flux energetiques de surface à partir des données satellitaires Landsat ETM+ [Spatialization of temperature and surface energy flows from Landsat ETM+ satellite data]. Revue Francaise de Photogrammetrie et de Teledetection. Vol. 2(190) p. 15-27.

MESSERER Y. 1999. Étude morphometrique et hydrologique du complexe lacustre d'El-Kala (cas du Lac Mellah et du Lac Oubeira) [Morphometric and hydrological study of the ElKala lake complex (case of Lake Mellah and Lake Oubeira)]. Université d'Annaba Algérie pp. 119.

Metz M., Mitasova H., Harmon R.S. 2011. Efficient extraction of drainage networks from massive, radar-based elevation models with least cost path search. Hydrology and Earth System Sciences. Vol. 15 p. 667-678.

MolnÁR G. 2016. Analysis of Land Surface Temperature and NDVI distribution for Budapest using Landsat 7 ETM+ data. Acta Climatologica et Chorologica, Universitatis Szegediensis. T. 49-50 p. 49-61.

Mouissi S., Alayat H. 2016. Utilisation de l'Analyse en Composantes Principales (ACP) pour la caractérisation physico-chimique des eaux d'un ecosystème aquatique : Cas du Lac Oubéira (Extrême NE Algérien) [Use of the Principal Component Analysis (PCA) for physico-chemical characterization of an aquatic ecosystem waters: Case of Oubeira Lake (Extreme Northeastern Algeria)]. Journal of Materials and Environmental Science. Vol. 7(6) p. 2214-2220.

Podsetchine V., ScherNEWSKi G. 1999. The influence of spatial wind inhomogeneity on flow patterns in a small lake. Water Resources. Vol. 33(15) p. 3348-3356.

RaOulT J.F. 1974. Géologie du centre de la chaîne numidique (Nord du constantinois, Algérie) [Geology of the centre of the numidic chain (Northern Constantine, Algeria)]. Thèse Sc. Mémoires de la Société géologique de France 121 N.S., LIII, pp. 163.

ReutTer H., Olesen F.S., Fischer H. 1994. Distribution of the brightness temperature of land surfaces determined from
A VHRR data. International Journal of Remote Sensing. Vol. 15 p. $95-104$

SAIFOUNI A. 2009. État des lieux des zones humides et des oiseaux d'eau en Algérie [Status of wetlands and waterbirds in Algeria]. MSc Thesis. El Harrach, Alger. Ecole Nationale Supérieure Agronomique (E.N.S.A.) pp. 250.

Sierra-Soler A., Adamowski J., Qi Z., SaAdat H., Pingale S. 2015. High accuracy Land Use Land Cover (LULC) maps for detecting agricultural drought effects in rainfed agro-ecosystems in central Mexico. Journal of Water and Land Development. No. 26 p. 19-35. DOI 10.1515/jwld-2015-0014.

Singh R.K., Senay G.B., Velpuri N.M., Bohms S., ScotT R.L., VERDIN J.P. 2014. Actual evapotranspiration (water use) assessment of the Colorado River Basin at the Landsat resolution using the Operational Simplified Surface Energy Balance model. Remote Sensing. Vol. 6 p. 233-256. DOI $10.3390 /$ rs6010233.

Ugur A., GordanA J. 2016. Algorithm for Automated Mapping of Land Surface Temperature Using LANDSAT 8 Satellite Data. Journal of Sensors. Article ID 1480307 p. 1-8. DOI 10.1155/2016/1480307.

USGS EROS Archive undated. What are the band designations for the Landsat satellites? [online]. [Access 30.12.2018]. Available at: https:/www.usgs.gov/faqs/what-are-banddesignations-landsat-satellites?qt-news_science_products $=0 \#$ qt-news_science_products

VILA J.M. 1980. La chaîne Alpine d'Algérie orientale et des confins Algérotunisiens [The Alpine chain of eastern Algeria and the Algerian-Tunisian borders]. PhD Thesis. Université Pierre et Marie Curie (Paris VI), 2 t pp. 665.

Weng Q., Lu D., Schubring J. 2004. Estimation of land surface temperature--vegetation abundance relationship for urban heat island studies. Remote Sensing of Environment. Vol. 89 p. 467-483. DOI 10.1016/j.rse.2003.11.005.

Wukelic G.E., GibBons D.E., MartucCi I.M., Foote H.P. 1989. Radiometric calibration of Landsat thematic mapper thermal band. Remote Sensing of Environment. Vol. 28 p. 339-347.

\section{Chouaib REZZAG BARA, Mohamed DJIDEL, Fethi MEDJANI, Sofiane LABAR}

\section{Przestrzenne i czasowe zmiany temperatury powierzchni ziemi w zlewni jeziora Oubeira w północnowschodniej Algierii}

\section{STRESZCZENIE}

Trudności w dostępie do badanych obszarów i w wykonaniu szczegółowych pomiarów temperatury powierzchni ziemi (LST) i wody (WST), szczególnie w środowiskach podmokłych, sprawiają, że dane pozyskane metodą teledetekcji są źródłem informacji do szacowania elementów klimatu takich jak temperatura powierzchni i emisyjność $(\varepsilon)$. Celem przedstawionych badań było określenie temperatury powierzchni siedlisk podmokłych jeziora Oubeira w północnowschodniej Algierii i jej zmian zarówno na ziemi, jak i w wodzie. W pracy wykorzystano obrazy Landsat OLI-TIRS z dwóch terminów (kwiecień i wrzesień 2016 r.) uzyskane z United States Geological Survey (USGS). Stanowiły one podstawę działań zmierzających do uzyskania końcowej temperatury LST - uzyskanie znormalizowanego różnicowego wskaźnika wegetacji (NDVI), konwersję numeru DN termicznego pasma podczerwieni (TIR) do spektralnej radiancji oraz obliczenie efektywnej temperatury barwowej sensora ze spektralnego promieniowania i emisyjności powierzchniowej $(\varepsilon)$.

Wyniki wskazują, że LST zmienia się w czasie i w przestrzeni (od 16 do $31^{\circ} \mathrm{C}$ w kwietniu i od 24 do $41^{\circ} \mathrm{C}$ we wrześniu). Oznacza to, że absorpcja temperatury przez pokrycie powierzchni ziemi zależy od optycznych właściwości powierzchni, które są określone przez zawartość wody, barwę i morfologię. Najniższą temperaturę wykazuje powierzchnia wody. Temperatura wody także ulega zmianom (od 19 do $25^{\circ} \mathrm{C}$ w kwietniu i od 26 do $34.5^{\circ} \mathrm{C}$ we wrześniu), wywołanym przez temperaturę powietrza, kierunek i prędkość wiatru oraz głębokość jeziora.

Słowa kluczowe: emisyjność, model SEBAL, temperatura powierzchni wody (WST), temperatura powierzchni ziemi (LST), zlewnia jeziora, znormalizowany różnicowy wskaźnik wegetacji (NDVI) 